\title{
The extent to which International Humanitarian Law provides protection for civilians: a brief discussion with reference to Myanmar
}

\author{
Barrister M Abul Fazal Chowdhury ${ }^{1}$
}

\begin{abstract}
The International Humanitarian Law (IHL) has not automatically come to us rather it arose from conscience in the form of evolution from Conventions to subsequent treaties, customary international law and case laws. This essay briefly explores how International Humanitarian Law (IHL) develops and protects civilians during the armed conflicts. It covers the consequence of breaching of such law and the implementation of IHL through international organisations such as UN, ICC, ICTY, and ICTR etc. the article also shows a close relationship between the International Humanitarian Law (IHL) and the International Criminal Law (ICL.) Finally this article also discusses on the humanitarian issues that rose in the Myanmar before its recent general election held on 8 November 2015.
\end{abstract}

Keywords: Armed Conflict, Civilians, Geneva Conventions, Humanitarian Law, International organisations,

\section{INTRODUCTION}

In this essay we shall have a look on the important milestones in the development of the International Humanitarian Law (IHL) that was emerged to protect the civilians through conventions, treaties, and case laws in internal and international armed conflicts. In all cases civilians are affected more specially women and children as they are the vulnerable group and constituted the major part of the world's population. As an example I choose the situation of Myanmar in relation to the violation of IHL as it bears a long history of armed conflict and it is subject to certain international humanitarian obligations relating to armed conflicts. For example, since August 1992, Myanmar has been a party to the four Geneva Conventions of 1949 that are considered largely to constitute customary international law. Myanmar's obligation is to carry out its military operations during the armed conflict according to the minimum standards established in common Article 3 of the Geneva Conventions ${ }^{2}$.

\section{DEVELOPMENT OF INTERNATIONAL HUMANITARIAN LAW:}

\subsection{St. Petersburg Declaration:}

In 1868 the declaration of St. Petersburg was the first to introduce limitations on the use of weapons of war. That declaration codified the customary principle, which is still valid today and prohibits the use of weapons which cause unnecessary suffering.

2.2The Brussels Declaration:

Though the Brussels Declaration of 1878 initiated by Russia was never ratified but many of its provisions were incorporated into the manual of the laws and customs of war adopted by the Oxford Manual in 1880.

2.3 The Hague Convention 1899:

Basically the Hague Convention 1899 was among the first formal statement of the laws of war and "war crimes" in the body of "secular international law ". It consists of four main sections as ${ }^{3}$

I. Creation of the permanent court of arbitration

II. Laws as customs of war on land

III. Adaption to Maritime warfare of principle of Geneva Convention 1864.

IV. Prohibition of launching of projectiles and explosive from balloons.

2.4 The Hague Convention 1907:

\footnotetext{
${ }^{1}$ Barrister M AbulFazalChowdhury is a Senior Lecturer, Department of Law and Justice at the Metropolitan University, Sylhet. He has completed his LL.B (Honours) at the University of London, UK, LL.M at London South Bank University in International Criminal Law and Procedure and BPTC at the City University, London, UK. He is a barrister member at the Honourable Society of the Middle Temple Inn, London, UK.

${ }^{2}$ Crimes in Burma- The International Human Rights Clinic, Havard Law School, 2009.

${ }^{3}$ The Hand Book of Humanitarian Law in Armed Conflict, Dieter Fleck page 19.
}

DOI: $10.9790 / 0837-2108053442 \quad$ www.iosrjournals.org $\quad 34 \mid$ Page


Actually the 1907 Hague Convention modified and added some 13 new sections regarding to the laws of war to the previous convention 1899. Although most of the powerful countries including USA, UK, Russia, France, China, Persia favoured a binding international arbitration, but Germany and some other countries had vetoed it. Thus the second conference,in general, failed with few major decisions and as a result the First World War took place.

\subsection{The World War 1 (1914-1918):}

During the war the world has experienced the evolution of aerial warfare. Though Article 25 of the Hague Regulation prohibited the attacks on undefended towns and villages, they were affected. The war also revealed the deficiencies in the legal protection of the wounded and prisoners of war and the widespread use of poison gas that led to the adoption of new Geneva Convention $1929 .{ }^{4}$

\subsection{The League of Nations:}

The League of Nations was formed as a result of the Paris Peace Conference, 1919, that ended the World War-I. It was the first international organisation whose principal mission was to maintain world peace. But it failed in preventing aggression by the axis power in the 1930s. Germany, Japan, Italy, Spain and others withdrew from league. The League of Nations was dissolved in 1946.

\subsection{Geneva Convention 1929:}

Geneva Convention for the Amelioration of the condition of the wounded and sick in armies in the field and the Convention relative to the treatment of prisoners of war were signed in Geneva. That Convention developed the terms of the Geneva Convention of 1906 and part of Hague Regulations of 1907. Basically the Geneva Conventions were the bitter experience of World War-I.

\subsection{Nuremburg Tribunal:}

Following the Moscow Declaration of 1 November 1943, the allied powers revealed their strong view to try the perpetrators of World War-II after the war. The jurisdiction was confined to three categories of offences

a) Crime against peace

b) War crime

c) Crime against humanity

Also the Nuremburg tribunal established some principles that are a set of guidelines for determining what constitute war crimes, crime against humanity or crime against peace.

\subsection{The United Nations:}

The United Nations (UN) is an international organization founded in 1945(24 October) after the World War-II aimed to maintain international peace and security, develop friendly relations among nations and promoting social progress, better living standard and human rights.

2.10 Geneva Convention, 1949- the legal basis of the IHL:

The four Geneva Conventions (GCs), of 1949 (12 august, 1949) come to be internationally binding upon all states:

a) GC-I for the Amelioration of the Condition of the Wounded and Sick in Armed Forces in the Field;

b) GC-II for the Amelioration of the Condition of the Wounded, Sick and Shipwrecked Members of Armed Forces at Sea;

c) GC-III concerning the Treatment of Prisoners of war;

d) GC-IV concerning the protection of the Civilian Persons in Time of War.

The two 1977 Protocols Additional to the Geneva Convention 1949 are designed to reaffirm and develop the rules embodied in the laws of Geneva and part of the laws of the Hague Convention 1907.

1) Additional Protocol-I (AP-1) 8 June, 1977 of the Geneva Convention 1949

2) Additional Protocol-II (AP-II) 8 June, 1977 of the Geneva Convention 1949.

The GCs of 1949 have achieved almost universal participation. The Conventions will therefore apply as treaties in almost any international armed conflicts. As of 11 May 2011, it had been ratified by 170 countries $^{5}$, including USA, Iran, Turkey, Pakistan, India, Israel and some others are exceptions. An

\footnotetext{
${ }^{4}$ Ibid 2 page 20

${ }^{5}$ ICRC www.icrc.org 
appeal by the ICRC on the $20^{\text {th }}$ anniversary of the adoption of Additional Protocols of 1977, are recognised as rules of customary international law.

2.11 ICRC and the IHL:

International Committee for Red Cross (ICRC) ${ }^{6}$ was established in 1863 with an objective to ensure protection and assistance to victims of armed conflict and strife. It does so through its direct action around the world and by encouraging the development of IHL and promoting respect to it. In the first World War it

i. appealed against the use of poisonous gases

ii. learned about protecting civilian

iii. urged to ban chemical warfare

iv. opened its international agency in Geneva

v. Listed about 5 million prisoners of war; visited most of them and enabled families to send relief parcel.

During the Second World $\mathrm{War}^{7}$, number of victims was higher among civilians than soldiers. Hitler regime waged a racial war aimed to wiping out Jews and gypsies. The problem was that the International Humanitarian Law included rules governing the treatment of prisoners of $\operatorname{war}^{8}$ but not that of the civilian population. Also the use of nuclear weapons caused destruction to the civilians more and that were not under proportional or distinguished principle. The ICRC is entirely dedicated in promoting the faithful application of the Geneva Conventions and their additional Protocols. It serves as a neutral intermediary between belligerents.

\subsection{The ICTY:}

The international Criminal Tribunal for the former Yugoslavia (ICTY) was established on 25 May 1993 by the United Nations Security Council Resolution 827 to try the perpetrators of crime committed since 1991; the grave violation of the GC, violation of the laws or customs of war, genocide, crime against humanity. These are deeply related to the protection of civilians 9 .

\subsection{The ICTR:}

The International Criminal Tribunal for the Rwanda (ICTR) was established in November, 1994 by the UNSC Resolution 955 in order to judge people responsible for the Rwandan genocide and other serious violation of international law between 1 January and 31 December $1994^{10}$.

\subsection{The SCSL:}

The Special Court for Sierra Leone (SCSL) is a judicial body set up on 16 January 2002 by the government of Sierra Leone and the UN to prosecute persons who bear greatest responsibilities for the grave violation of international humanitarian law and SL law during the Sierra Leone civil war after 30 November $1996^{11}$.

\subsection{The ICC:}

The International criminal Court (ICC) is the permanent court established by the Rome Statute, 1998. It entered into force in 1 July $2002 .{ }^{12}$ The basic aim is to judge the people accused of crime against humanity, genocide, war crimes and crime of aggression ${ }^{13}$. The establishment of these institutions aim to maintain the peace in the world to follow the laws and customs of war and protection of civilian.

\section{PROTECTION OF CIVILIAN}

As the military strategy changes, the threat to the civilian increases. If we look at the World War-I, only 5 per cent, approximately of all causalities were civilian. But by the end of World War-II, this figure has gone up to 50 per cent and is continuously on rise. Out of 20 million in 150 armed conflicts between 1945-1982; the majority of deaths were women and children. ${ }^{14}$ So the protection of civilian is a vital issue during armed conflicts.

3.1 Definition of civilian:

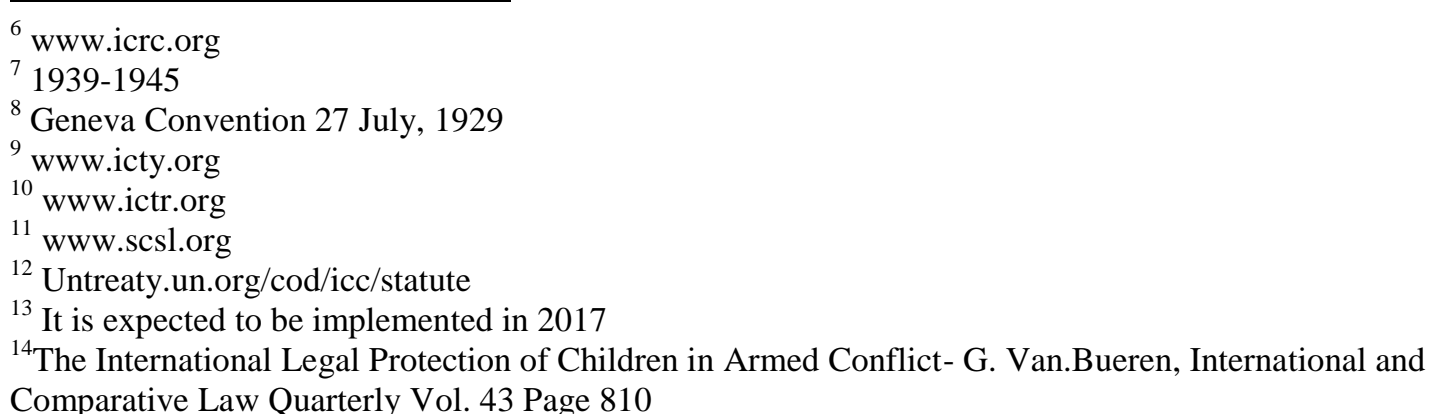

DOI: $10.9790 / 0837-2108053442 \quad$ www.iosrjournals.org $\quad 36 \mid$ Page


The dictionary meaning of civilian is a person following the pursuits of civil life, especially one who is not an active member of the military, police or belligerent group. Article 50 (1) of the AP-1 of 8 June 1977 to the GC-IV, 1949 states that a civilian is any person who does not belong to one of the categories of persons referred to in Article 4 (A) (1) (2) (3) and (6) of the GC-11l and in Article 43 of this protocol. In case of doubt whether a person is a civilian; that person shall be considered to be a civilian. The presence within the civilian population of individuals who do not come within the definition of civilians does not deprive the population of civilian character.

Article $4 \mathrm{~A}$ of the Third Convention ${ }^{15}$ states that

(1) Prisoners of war in the sense of the present convention are persons belonging to one of the following categories who have fallen in to the power of enemy;

(2) Members of the militias and members of other volunteer corps, including those of organised resistance movements belonging a party to the conflict and operating in or inside their own territory even if this territory is occupied, provided that such militants or volunteer corps, including such organised resistance movements fulfil the following conditions:

a) that of being commanded by a person responsible for his subordinates;

b) that of having a fixed distinctive sign recognisable at a distance;

c) carrying arms openly;

d) that of conducting their operations in accordance with the laws and customs of war.

(3) Member of regular armed forces who profess allegiance to a government or an authority not recognised by the detaining power.

(6) Inhabitant of a non-occupied territory, who on the approach of the enemy spontaneously takes up arms to form themselves into regular armed units, provided they carry arms openly and respect the law and customs of war.

Article 43 of the AP- $1^{16}$ states;

1. The armed forces of a party to a conflict of all organised armed forces, groups and units which are under a command responsible to that party for the conduct of its subordinates, even if that party is represented by the government or an authority not recognised by an adverse party. Such armed forces shall be subject to an internal disciplinary system which, inter alia, shall enforce compliance with the rules of international law applicable in armed conflict.

2. Members of armed forces of a party to a conflict (other than medical personnel and Chaplains covered by article 33 of the Third Convention) are combatants, that is to say they have the right to participate directly in hostilities.

3. Whenever a party to a conflict incorporates a paramilitary or armed law enforcement agency in to its armed forces it shall so notify the other parties to the conflict.

So from the above discussion we have got populations who are treated as civilian.

3.2 Two regimes of armed conflict:

It is very difficult to assess whether an armed conflict is internal or international. The reason is that most of the armed conflicts are primarily formed internally then it turned in to internationally. In Prosecution $\mathrm{v}$ Tadic $^{17}$ case the appeal Chamber of the ICTY held that, the conflict of the former Yugoslavia could have been characterised as both internal and international, or as an internal conflict alongside an international one, or as an internal conflict that had become international because of external support, or as international conflict that has a subsequently been replaced by one or more internal conflicts or some combination thereof ${ }^{18}$.

\subsection{International Armed Conflict (IAC):}

The armed conflict that is influenced by other country is simply called International Armed Conflict. In case of IAC the rules are comprehensively stated in the four Geneva Conventions, AP-1 and specific treaties deal with the means of warfare.

\subsection{Non-International Armed Conflict (NIAC):}

In case of non-international armed conflict, it requires a thorough knowledge of the constitution and the domestic law of the state in question, Article 3, common to the four Geneva conventions, AP-II, the Customary

\footnotetext{
${ }^{15}$ Geneva Convention III 1949.

${ }^{16}$ Additional Protocol 1, 1977 of the GC 1949.

${ }^{17}$ Procutor v Tadic, case no. IT-94-1,icty.

${ }^{18}$ Classifying the conflict: a soldiers' dilemma- Andrew J. Carswell International Review of the Red cross no.873,30/3/2009, www.icrc.org
} 
law of IHL, IHRL and relevant Articles of the Rome Statute, 1998 of the ICC. Article 3 applies in the case of armed conflict not of an international character occurring on the territory of a state party to the GCs, but the Article does not further define the threshold at which such a conflict begins.

However, the most authoritative definition of armed conflict is contained in the ICTY's Appeal Chamber decision on jurisdiction in the Tadic case ${ }^{19}$ "we find out an armed conflict exists whenever there is resort to armed force between state or protected armed violence between government authorities and organised armed groups or between such groups within the state. The IHL applies from the initiation of such armed conflicts and extends beyond the cessation of hostilities until a general conclusion of peace is reached; or, in the case of internal conflicts a peaceful settlement is achieved. Until that moment, IHL continues to apply in the whole territory of the warring states or, in the case of internal conflicts, the whole territory under the control of a party whether or not actual combat takes place there".

This view or test is reflected in article 8(2) (f) of the Rome statute, 1998. Common article 3 that recognised within customary law as the absolute minimum of humanitarian treatment applicable during armed conflict of any legal qualification ${ }^{20}$

The Trial Chamber of the ICTR stated that "it should be recalled that the four GCs as well as the Two Protocols were adopted primarily to protect the victims as well as potential victims of armed conflicts. If the application of IHL dependent solely on the discretionary judgement of the parties to the conflict, in most cases there would be a tendency for the conflict to be minimised by the parties thereto ${ }^{21}$ ".

So from the above discussion we can say that the IHL is applicable in both internal as well as international armed conflicts.

\subsection{Is Myanmar's Situation an Internal or International armed conflict?}

Myanmar got independence on $4^{\text {th }}$ January, 1948. Since its independence civil war is a constant feature of Myanmar's socio-political landscape. As of 2012, the on-going conflict in the country included the Kachin conflict, the Rohinga in Arakan state, as well as Shan, Lahu and Karen in the eastern half of the country. So in this sense may be referred to as the internal armed conflict among the government forces and the Ethnic groups. On the other hand, it is also called an international armed conflict as some countries especially China, Russia and South Korea directly supported Myanmar's military government in that conflict. In 2009 Myanmar was found to deal with the prohibited weapons with North Korea ${ }^{22}$. In 2007, the UNSC $^{23}$ invoked to pass sanctions against Myanmar but Russia and China vetoed on that proposal. In that sense it can be treated as an international armed conflict.

\section{GENERAL PROVISIONS TO PROTECT CIVILIAN}

3.1 Civilians should be respected and protected:

Article 27 Para 1 of the GC-IV, Article 46 Para 2 of the Hague Reg. stated that civilians are entitled to respect for their persons, their honour, their family rights, their religions conviction and their manners and customs. Article 46 Para 2 of the Hague Reg. stated that their property is also protected. Article 51, Para 2 of the AP-I, Article 13 Para 2 of the AP-II stated that neither the civilian population as such, nor individual civilians, shall be attacked, killed, wounded, or taken prisoner without sufficient reason.

3.2 Torture and Killings are prohibited:

Article 31,147 of the GC-IV state that, any physical or moral coercion to obtain, for example, information is strictly prohibited and it is punishable. It is seen as a grave breach of the Conventions and it constitutes "war crime". ${ }^{24}$ Again in Article 12, Para 2 of GC-II and Article 11 Para 1 of the AP-1, it is also prohibited to undertake medical and scientific experiments or organ transplant that is not therapeutically justified. In Myanmar, the special Rapporteur on extra judicial, summery or arbitrary executions, Civil and Political Rights, Including the Question of Disappearances and summary Execution; delivered report to the UN Economic and Social Council showed that, extra judicial killing, summary trial, torture were conducted by soldiers during the conflicts. $^{25}$

\footnotetext{
${ }^{19}$ Prosecution v Tadic, Appeal chamber's decision of 2 October 1995, Para 70.

${ }^{20}$ ICJ case in Nicaragua v USA (1986), Para 218.

${ }^{21}$ Prosecution v Akayesu, Trial Chamber judgment on 2 September 1998, Para 603

${ }^{22}$ Oversight Committee Resolution 1874.

${ }^{23}$ UN Security Council $5619^{\text {th }}$ meeting, 12 January 2007.

${ }^{24}$ The Convention against Torture and Other Cruel, Inhuman or Degrading Treatment or Punishment, 10 December, 1984.

${ }^{25}$ UN Doc. E/C N 4/2006/78/Add.1, January, 18, 2006.

DOI: $10.9790 / 0837-2108053442$

www.iosrjournals.org 38 | Page
} 
3.3 Forced removal is prohibited:

With an exception of Article 49, Para 2 of the GC-IV, it is prohibited to do forced removal of protected persons from their place of residence. Article 46 Para 2 of the Hague Reg. guarantees that the personal property of civilian shall also be protected. Article 53 of the GC-IV comprehensively prohibited the occupying power from destroying movable or immovable property of inhabitants of the occupied territories. Article 147 of the GC-IV states unlawful and wanton destruction or appropriation of property on a large scale that cannot be justified by military necessity and it is a grave breach of the meaning of the Article.

In Myanmar the Special Rapporteur observed that conflict between military authority and non-state armed groups resulted that over a million of people are understood to have been displaced from their homes during the time 1996-2006. Only in November, 2006 the number of internally displaced person is estimated to be at least $500,000 .{ }^{26}$ The UNHCR has showed that as of 28 January 2013 some 30,000 registered refugees and an estimated 200,000 unregistered Rohinga living outside the camp and to local villages in the poverty stricken country Bangladesh. ${ }^{27}$ A group of six UN Rapporteurs and experts released a joint statement in May 2006 that stated the operations had resulted in the forcible eviction and displacement of thousands of ethnic minority villagers. So this is a grave breach of the above Articles.

\subsection{Right to get relief:}

Article 23 of the GC-IV and Article 70 of AP-1 stated that every state and in particular the adversary is obliged to grant relief actions, free transit by neutral countries or humanitarian organisations. Article 54 of AP-1 expressly prohibited starvation of civilian population of the enemy, also starvation as a method of warfare is prohibited. So passage of such relief action must be allowed. Third states not involved in the conflict are bound by these Articles to allow free passage through their territory. Again Myanmar is also obliged to allow international relief organizations to distribute relief among needy people. The UN Under-Secretary -General for Humanitarian Affairs and Emergency Relief Coordinator Baroness Valerie Amos met president U TheinSein on $6^{\text {th }}$ December 2012 during her four days visit in Myanmar and publicly urged to allow the UN to resume aid consignments to refugee camps in non-government controlled parts of Kachin state held by (KIO) where some 40,000 people who have been displaced by warfare between government troops and Kachin Independence Organization (KIO) as the government refused to give access to the UN to distribute relief ${ }^{28}$.

4.5 Rights not to be used as shield: Article 28 of the GC-IV and Article 51 Para 7 of the AP-I stated that none of the parties to the conflict shall use civilians as shield to render certain points or areas immune from military operations. Also article 33 Para 3 of the GC-IV, Article 51 Para 2 and 6 of the AP-I, Article 13 Para 2 of the AP-II prohibited collective penalties and measure of intimidations or terrorism, reprisals against civilian and their property. Human Rights Watch Report 2012 on Burma ${ }^{29}$ showed that in January Burmese army units in Karen State forced convicts to work as porters in on-going operation in combat zones. They are forced to carry military supplies and material to the frontline, often being used as "human shields" to deter attack or clear anti-personnel landmines

\section{SPECIAL PROVISIONS TO PROTECT CIVILIANS:}

3.5 Protection of Women:

Human Rights Watch, Untold Terror: Violence against Women, Peru's armed Conflicts: A report by American Watch and Women Right Project (1992), Amnesty International Report on Bosnia-Herzegovina; Rape and Sexual abuses by Armed Forces (1993), Helsinki Watch on war Crimes in Bosnia-Herzegovina (1992), Final Report of the Commission of Experts Established Pursuant to Security Council Resolution 780 (1992), that considers the issue of Rape and Sexual assault against women, Human Rights Watch, Global Report on Women's Human Rights (1995), The Fourth World Conference on Women, Beijing, China $4^{\text {th }}$ September, 1995, Amnesty International Report on the Gulf War and many other studies showed that women, increasingly, bear the major burden of armed conflict ${ }^{30}$. In recent years, particular attention has been given to the question of violence against women in armed conflict. In 1995 the Beijing platform for action calls on governments, the international community and civil society including NGOs and the private sector to take the strategic action. Also reports, interviews of victims of armed conflicts have revealed that women experienced armed conflict in a

\footnotetext{
${ }^{26}$ UN Doc.E/CN.4/2006/34 (Feb.7, 2006)

${ }^{27}$ www.UNHCR.org

${ }^{28}$ www.un.org/apps/news

${ }^{29}$ www.hrw.org/world report-burma-2012

${ }^{30}$ Protection of women in Armed Conflict-Judith Gardam and Hilary Charlesworth, Human Rights Quarterly
} vol. 22. 
different way than $\operatorname{man}^{31}$. Article 27 Para 2 of the Fourth GC, Article 76 Para 1 of AP-II state that any attacks on the honour of women, in particular rape, enforced prostitution, or any form of indecent assault is prohibited. These provisions also states, if a pregnant women or a mother with small children is detained on suspicion of an offence, then her case should be treated on priority basis and they shall not be sentenced to death. This rule is applicable to all situations to which GC-IV and AP-1 are applicable.

In case of Myanmar, Mr Pinheiro, the UN Special reporter from 2000-2008 stated that he received reports of 265 woman and girls in Shan State that they were violently attacked during the conflict and this trend continued in the period of 2002-2005, ${ }^{32}$ during that period he received 188 rape cases in Shan State, it also extended to other civilians in ethnic nationality areas such as Karen, Man etc. The 2008 report of the Committee on the Elimination of Discrimination against Woman (CEDAW) revealed that a high level of attacks have continued throughout the period since 2002. The report concerned on the high prevalence of violence against women and girl such as widespread domestic violence and sexual violence including rape ${ }^{33}$ Rape is seen as a crime against humanity under Article 7(1) (g) and as a war crime under Article 8 (2) (e) (VI) of the Rome statute 1998. The scope of violence against women have broadened in recent cases before the international Tribunals, for example in $\mathrm{AFRC}^{34}$ and in $\mathrm{RUF}^{35}$ case the SCSL for the first time ever tried "forced marriage" as a crime against humanity.

\subsection{Protection of Children:}

The GC-IV incorporates 17 Articles of specific concern to children. Article 24 of the GC-IV; Article 77 Para 1 of the AP-I states that children shall be the object of special respect and protection. They shall be provided with the care and aid they require, whether because of their youth or for any other reasons. Para 3 of Article 77 of the AP-I states that children who have not attained the age of 15 shall not take part in hostilities, they shall not be enlisted. If they fall into the power of an adverse party, they shall be granted special protection. The Convention on the rights of Child (CRC) 1989, is the first UN human rights treaty that includes a provision in Para 2 and 3 in Article 38 that oblige state parties to take all feasible measure to ensure that persons under 15 do not take direct part in hostilities and refrain from recruiting persons between the age of 15 and 18. Again Article 14 of the CRC states that, state parties should respect the right of child to freedom of thought, conscience and religion. Article 18 of the International Convention on Civil and Political Right, Article 1 of the Declaration on the Elimination of All Forms of Intolerance and of Discrimination Based on Religion and Belief also support these rights. The CRC allows no derogations in times of emergency, and today the CRC received almost universal ratification. ${ }^{36}$ Article 24 Para 1 of GC-IV states even children who are orphaned and children who are separated from their families as a result of the war or other reasons shall not be left to their own resources. Article 77, Para 5 of the AP-I also states that if a person sentenced to death for an offence related to the armed conflict was below 18 years of age at the time the offence was committed, then the sentence shall not be carried out. Article 24 Para 2 of the GC-IV states, with the consent of the protecting power, such children may be taken to a neutral country for the duration of the conflict.

However, in the case of Angola, Somalia, Sudan, former Yugoslavia, Gaza, Myanmar and very recent case in Syria have focused attention on the right of children. If we look at the UNICEF report ${ }^{37}$ we can see that in the last decade, more than 2 million children have died as a direct result of armed conflict, and more than three times that number have been permanently disabled or seriously injured. An estimated 20 million children have been forced to flee their homes and more than 1 million have been orphaned or separated from their families. Some 300,000 child soldiers' boys and girls under the age of 18 are involved in more than 30 conflicts worldwide ${ }^{38}$

According to the press conference on $5^{\text {th }}$ July $2012^{39}$ by the UN it has revealed that there was also a recruitment of child soldiers in armed forces in Myanmar. An action plan was signed between the UN and the government of Myanmar to end the recruitment and use of child soldier. So enlisting child soldier is seen as a

\footnotetext{
${ }^{31}$ Ibid 17

${ }^{32}$ Un Doc. A/61/369 (Sep. 21, 2006).

${ }^{33}$ UN Doc. CEDAW/C/MMR/CO/3 (November 7, 2008).

${ }^{34}$ Prosecutor v Brima, Kamara and Kanu

${ }^{35}$ Prosecutor v Sesay, Kallon and Gbao

${ }^{36}$ International Law and Child Victim of Armed Conflict- Is the "first call" for children?- Bo Victor Nyluend.

The International Journal of Children's Rights 6 23-53, 1998.

${ }^{37}$ UNICEF Humanitarian Action Report 2005, P VII

${ }^{38}$ The International Legal Protection of Children in Armed Conflict- Geralidine Van Bueren, International and Comparative Law Quarterly Vol.43 Page 809-826.

${ }^{39}$ www.un.org/news 
crime against humanity. If we look at the ICC case, particularly Thomas Lubanga ${ }^{40}$ case, we can see that he was found guilty of enlisting and conscripting child soldiers and using them to participate actively in hostilities under Article 8(2) (e) (VII) of the Rome Statute, 1998, on the 14 March 2012. In Prosecution v Sam Hinga Norman $^{41}$, a motion was filed by the defence counsel on the basis that the court had a lack of jurisdiction and individual responsibility on child recruitment into armed forces. The court considered Article 38 of the ICJ, Article 14, 24 of GC-IV, Article 77 of the AP-1, Article 4 of the AP-II, Article 4, 38 of the CRC, Article 22(2) of the African Charter on the Rights and Welfare of the Child, and the International Customary Law, the SCSL rejected that motion. In Charles Taylor case, ${ }^{42}$ he was found guilty of 11 counts (26 April 2012) including crime of conscription of children under 15 years into armed force. The Court found that children were forcibly abducted and forced to undergo military training.

\section{CONCLUSION}

In any armed conflict whether it is international or non-international, the international humanitarian law is applicable to protect the civilians. Civilians are always protected and their rights should be respected in any situation. International organisations such as the UN, the ICC and others were established to implement the international humanitarian law. Sometimes the International Community express their deep concerns about the grave violations of International Humanitarian law. Sometimes they effectively take steps e.g. imposes sanctions as primary step on the law breaching country but sometimes the international community seems to be helpless e.g. in Myanmar situation. However the perpetrators should be brought under the international law for trial. Though there are many instances before us that perpetrators have been tried through forming international tribunals, still there some pull factors which work as obstacles to try the perpetrators. The international community should come forward to overcome these pull factors and ensure the fair trial.

\section{Books:}

[1] Fleck D, (Ed) The hand Book of Humanitarian Law in Armed Conflict, Oxford University Press, $2^{\text {nd }}$ Edition, 2008.

[2] Green L C, The contemporary law of armed Conflict, $3^{\text {rd }}$ Edition, Manchester University Press, 2000.

[3] Cassese A, International Criminal Law, $2^{\text {nd }}$ edition, OUP, 2008.

\section{CONVENTIONS ANDSTATUTES}

[5] The Hague convention 1899.

[6] The Hague convention 1907.

[7] Geneva Convention (GC)-I for the Amelioration of the Condition of the Wounded and Sick in Armed Forces in the Field;

[8] GC-II for the Amelioration of the Condition of the Wounded, Sick and Shipwrecked Members of armed Forces at Sea;

[9] GC-III concerning the Treatment of Prisoners of war;

[10] GC-IV concerning the protection of the Civilian Persons in Time of War.

[11] Additional Protocol-I, 8 June, 1977 of the Geneva Convention 1949

[12] Additional Protocol-II, 8 June, 1977 of the Geneva Convention 1949.

[13] The Convention on the rights of Child (CRC) 1989,

[14] The Rome Statute of International Criminal Court (ICC) 1998.

[15] The Convention against Torture and Other Cruel, Inhuman or Degrading Treatment or Punishment, 10 December, 1984.

Articles:

[16] Crimes in Burma- The International Human Rights Clinic, Harvard Law School, 2009.

[17] The International Legal Protection of Children in Armed Conflict- G. Van. Bueren, International and Comparative Law Quarterly Vol. 43

[18] International Law and Child Victim of Armed Conflict- Is the "first call" for children? - Bo Victor Nyluend. The International Journal of Children's Rights 6 23-53, 1998

[19] International Law and Child Victim of Armed Conflict- Is the "first call" for children?- Bo Victor Nyluend. The International Journal of Children's Rights 6 23-53, 1998.

\footnotetext{
${ }^{40}$ Prosecutor v Thomas Lubangadyilo, ICC-01/04-01/06-2842,TC,14 March 2012.

${ }^{41}$ Case no. scsl-2004-14-AR72(E).

${ }^{42}$ Prosecutor v Charles Taylor case no. SCSL-03-1-T

DOI: $10.9790 / 0837-2108053442 \quad$ www.iosrjournals.org


[20] Protection of women in Armed Conflict-Judith Gardam and Hilary Charlesworth, Human Rights Quarterly vol. 22.

[21] Classifying the conflict: a soldiers' dilemma- Andrew J. Carswell International Review of the Red cross no.873,30/3/2009, www.icrc.org

Cases:

[22] Prosecution v Tadic, Appeal chamber's decision of 2 October 1995, Para 70.

[23] ICJ case Nicaragua v USA (1986), Para 218.

[24] Prosecution v Akayesu, Trial Chamber judgment on 2 September 1998, Para 603.

[25] Prosecutor v Brima, Kamara and Kanu(AFRC Case)(case no. scsl-04-16-T-261).

[26] Prosecutor v Sesay, Kallon and Gbao(RUF case)(case no scsl-04-15-T)

[27] Prosecutor v Thomas Lubangadyilo, ICC-01/04-01/06-2842,TC,14 March 2012.

[28] Prosecutor v Charles Taylor case no. SCSL-03-1-T

\section{Other sources:}

[29] ICRC www.icrc.org

[30] www.icty.org

[31] www.ictr.org

[32] www.scsl.org

[33] Untreaty.un.org/cod/icc/statute

[34] UN Doc. E/C N 4/2006/78/Add.1, January, 18, 2006.

[35] UN Doc.E/CN.4/2006/34 (Feb.7, 2006)

[36] www.UNHCR.org

[37] www.hrw.org

[38] Un Doc. A/61/369 (Sep. 21, 2006).

[39] UN Doc. CEDAW/C/MMR/CO/3 (November 7, 2008). 